\title{
TAUSIYAH PENDAKWAH DI YOUTUBE MENGENAI NIKAH SIRRI: INTERPRETASI DAN PENGAITAN HUKUM
}

\author{
Kholifatun Nur Mustofa \\ Institut Agama Islam Negeri (IAIN) Salatiga
}

\begin{abstract}
Abstrak
Youtube merupakan salah satu sarana untuk menyebarkan tausiyah pendakwah, melalui Youtube tersebut masyarakat bisa mengakses tausiyah kapanpun dan dimananpun. Pembahasan yang ditawarkan salah satunya adalah ceramah yang disampaikan oleh Mamah Dedeh dan Ustadz Abdul Somad (UAS) tentang nikah sirri. Penulis menggunakan kedua pendakwah tersebut untuk memfokuskan bahasan dan tema. Penulis menggunakan media youtube sebagai sumber penelitian. Kemudian paper ini fokus pada pembahasan bagaimana interpretasi pendakwah tentang nikah sirri. Apakah tausiyah Mamah Dedeh dan UAS menyampaikan nikah sirri dengan mengaitkan ketentuan Hukum Islam dan hukum Negara. Hasil penelurusan penulis, Mamah Dedeh memahami konteks nikah sirri yang dilakukan sekarang ini berbeda dengan nikah sirri yang diterapkan nabi, pernikahan sirri yang dilakukan oleh masyarakat saat ini adalah pernikahan yang dilakukan secara sembunyi-sembunyi, bahkan syarat pernikahan tidak semua terpenuhi. Sehingga pernikahan tersebut tidak sah karena tidak memenuhi syarat. Mengenai penyampaian ceramah yang mengaitkan hukum Negara dan hukum Islam, Mamah Dedeh tegas dalam menyampaikan bahwa pernikahan yang memenuhi rukun dan syarat tidak cukup. Beliau menegaskan bahwa di Indonesia mempunyai aturan tentang pencatatan perkawinan yang memberikan perlindungan kepada perempuan. Sedangkan UAS tidak mengaitkan hukum Negara dan hukum Islam. UAS sekedar menyarankan untuk tidak melakukan nikah sirri karena banyak dampak yang membahayakan untuk perempuan.
\end{abstract}

Kata kunci: Pendakwah; media; Interpretasi nikah sirri.

Youtube is one of the means to spread preaching tausiyah; through Youtube, people can access tausiyah anytime and anywhere. One of the discussions offered was a lecture delivered by Mamah Dedeh and Ustadz Abdul Somad (UAS) about sirri marriage. The author uses the two preachers to focus the discussion and theme. First, the author uses YouTube as a research source. Then this paper focuses on discussing how the preacher interprets the sirri marriage. Do tausiyah Mamah Dedeh and UAS convey sirri marriage by linking Islamic law and state law? The results of the author's search, Mamah Dedeh understands that the context of sirri marriages being carried out today is different from the sirri marriages applied by the prophet, sirri marriages carried out by the community today are marriages that are carried out secretly, even the conditions of marriage are not all fulfilled. So the marriage is invalid because it does not meet the requirements. Regarding the delivery of a lecture linking state law and Islamic law, Mamah Dedeh was firm in 
conveying that a marriage that meets the pillars and conditions is not enough. He emphasized that in Indonesia, there are regulations regarding the registration of marriages that protect women. Meanwhile, UAS does not link state law and Islamic law. UAS advises not to do unregistered marriages because there are many harmful effects for women.

Keyword: Preacher; Media; Interpretation of sirri marriage.

\section{A. Pendahuluan}

Pernikahan merupakan salah satu sunnah rasul, pernikahan tersebut menimbulkan ikatan yang kuat dan mulia dengan tujuan untuk mewujudkan kehidupan rumah tangga yang sakinah, mawaddah dan rahmah. Selain mewujudkan keluarga yang bahagia, pernikahan juga bagian dari melakukan perintah Allah. ${ }^{1}$ Rasulullah SAW berkata "pernikahan yang dilangsungkan sebaiknya akad nikah dilakukan di masjid, lalu pernikahan tersebut di umumkan serta memukul rebana". Pengumuman tersebut bertujuan supaya tamu yang hadir menjadi saksi terjadinya pernikahan yang dilakukan oleh mempelai laki-laki dan perempuan. Selain itu supaya pernikahan tersebut dapat dipertanggungjawabkan dan menghindari isu negatif antara kedua mempelai. ${ }^{2}$ Ikatan kuat dalam pernikahan diwujudkan dengan cara melakukan pencatatan pernikahan sebagai salah satu bukti tertulis. ${ }^{3}$

Pelaksanaan pernikahan di atas terkadang membuat pembedaan antara syarat pernikahan menurut Hukum Islam dan hukum Negara, seakan kedua hukum tersebut saling bertentangan dan tidak bisa saling melengkapi. Pemahaman kedua aturan tersebut menjadikan pengelompokan menjadi nikah secara agama dan nikah secara agama. Pernikahan agama seringkali disebut nikah sirri. Sebagian masyarakat memahami nikah sirri sebagai pernikahan yang sudah memenuhi syarat pernikahan namun tidak dicatatkan ke KUA. Pemahaman masyarakat bisa dipengaruhi oleh pemahaman ulama atau kyai yang sudah dianggap mumpuni dalam bidang agama. Hal itu dijadikan sumber informasi oleh masyarakat.

\footnotetext{
1 Abd Basit, Misbachul Fitri, and Khusnul Kholik, "Pendampingan Pra Nikah Sebagai Solusi Mencari Pasangan Ideal Bagi Santri Senior Pondok Pesantren Miftahul Mubtadiin Putra Ar-Ridlo Krempyang Tanjunganom Nganjuk" 3, no. 1 (2020), p. 61-62.

2 Asripa Asripa, "Nikah Sirri Dalam Perspektif Islam," Imtiyaz: Jurnal Ilmu Keislaman 4, no. 1 (2020): 54-55, https://doi.org/10.46773/imtiyaz.v4i1.64.

${ }^{3}$ Farihatni Mulyati, "Interpretasi Mitsaqan Ghalizan Dalam Surah An-Nisa (4) : 2( Pentingnya Pencatatan Pernikahan Menurut Hukum Islam )" 12, no. 22 (2014), p. 37.
} 
Sistem informasi klasik untuk mendapatkan ilmu agama yaitu dengan cara mendatangi suatu pondok untuk bertanya tetang permasalahan yang sedang ia alami kepada kyai pondok. Sedangkan sekarang kemajuan bidang teknologi membuat model pembelajaran tidak lagi harus bepergian yang jauh dan memberikan kemudahan kepada pengguna. Salah satu kemudahan yang bisa memudahkan pengguna adalah internet. Tekhnologi atau bantuan internet memberikan kemudahan masyarakat untuk menembus batas geografis dan waktu. ${ }^{4}$ Mengakses konten melalui Youtube memudahkan masyarakat mulai dari anak-anak hingga orang tua bisa mengakses tausiyah dengan mudah sesuai dengan topik dan pembicara yang berbeda-beda sesuai konten yang dipilih dan disukai. ${ }^{5}$

Pemaparan Ahmad sejalan dengan pemaparan Syifa, ia mengungkapkan bahwa tausiyah atau ceramah tidak hanya dinikmati dan ditonton dalam satu waktu tetapi bisa dinikmati dan didengarkan kapanpun dan dimanapun melalui teknologi, salah satunya adalah media youtube. Pendakwah bisa membagikan tausiyahnya kepada masyrakat melalui Youtube. Hal itu memudahkan masyarakat untuk memahami dengan baik isi tausiyah yang disampaikan oleh pendakwah. ${ }^{6}$ Sistem ceramah memberikan kemanfaatan kepada audiensi untuk memberikan wawasan dan informasi yang bertujuan untuk memberikan motivasi yang berkaitan dengan akhirat atau urusan yang lain. Penceramah biasanya memberikan arahan supaya audiensi untuk melakukan apa yang diuraikan oleh pendakwah. Tujuannya supaya audiensi atau jamaah dapat mengamalkan apa sesuai dengan petunjuk yang disarankan oleh pendakwah.7

Youtube menjadi salah satu media yang efektif digunakan untuk menyebar berbagai informasi karena mampu menjangkau lebih luas dibandingkan dengan

4 Abu Muslim, "Pergeseran Otoritas Ulama Magetan Akibat Fragmentasi Media Dakwah Baru Yang Ekonomis," Spiritualis 5, no. 1, Maret (2019), p. 34-35.

5 Ahmad Tamrin Sikumbang and Rahmi Fiutra Ulwani, "Youtube As a Da'Wah Media," Jurnal Al-Bayan: Media Kajian Dan Pengembangan Ilmu Dakwah 26, no. 2 (2021), p. 268-269.

6 Syifa Hayati Islami, Lina Agustina, and M. Fathur Rochman, "Pemikiran Dan Aktivitas Dakwah Ustadz Abdul Somad Melalui Media Sosial Youtube," Tsaqila: Jurnal Komunikasi Dan Penyiaran Islam 1(1) (2020), p. 44-45.

7 Alfiyani Nur Safitri, Asep Purwo, and Yudi Utomo, "Analisis Tindak Tutur Direktif Pada Ceramah Ustadz Abdul Somad Edisi Tanya Jawab Kajian Musawarah Bersama Artis Hijrah," ESTETIK: Jurnal Bahasa Indonesia 3, no. $2 \quad$ (2020), p. 120-121. https://doi.org/10.29240/estetik.v3i2.1613. 
tausiyah yang dilakukan secara langsung. Media yang ditawarkan di Youtube sangat beragam, mulai dari ceramah serial yang berdursi 50 menit, video ceramah singkat yang berdurasi 10-15 menit, potongan ceramah, cerita singkat serta musik serta video komunitas. Oleh karena itu dakwah di media Youtube menjadi salah satu alternatif untuk menyebarkan informasi kepada masyarakat yang lebih luas. ${ }^{8}$

Youtube merupakan salah satu media yang digunakan pendakwah untuk menyampaikan tausiyah melalui media sosial. Media tersebut cenderung lebih menarik dibandingkan televisi. Konten yang diunggah melalui youtube biasanya lebih lengkap serta tanpa di batasi waktu dan tempat. Selain itu masyarakat juga bisa menyaksikan konten sesuai dengan konten yang diminati. ${ }^{9}$ Penggunaan Youtube dilakukan sebagai distribusi pemikiran dan pemahaman keagamaan. Konten Youtube dipilih oleh pendakwah sebagai media untuk distribusikan pemikiran dan paham keagamaan supaya penyebaran tausiyah bisa menyebar lebih luas. ${ }^{10}$ Sebelum adanya Youtube sebagai media dakwah, televisi merupakan salah satu media yang digunakan oleh pendakwah untuk menyebarluaskan tausiyahnya.

Televisi memberikan informasi kepada masyarakat luas, selain itu televisi juga memiliki daya tarik yang kuat karena dalam tayangan televise tersebut menyajikan berbagai informasi. Informasi tersebut diberikan sound effect yang menjadikan masyarakat tertarik untuk menonton berita dari televisi. Berbagai muatan disajikan, mulai dari berita, informasi, hiburan serta pendidikan disajikan. Televisi juga menjangkau banyak masyarakat tanpa membutuhkan jaringan internet. ${ }^{11}$

Penelitian terdahulu tentang nikah sirri sudah pernah dilakukan. Asripa misalnya mengungkapkan bahwa nikah sirri diperbolehkan menurut Hukum Islam, yaitu semua syarat sudah terpenuhi kecuali mencatatkan pernikahan tersebut ke Kantor Urusan Agama (KUA). Biasanya nikah sirri tersebut dilaksanakan dengan

${ }^{8}$ Hamdan and Mahmuddin, "Youtube Sebagai Media Dakwah," Palita: Journal of Social Religion Research 6, no. 1 (2021), p. 68-77.

${ }^{9}$ Abdul Salam, Muliaty Amin, and Kamaluddin Tajibu, "Dakwah Melalui Youtube (Analisis Pesan Dakwah Ustadz Hanan Attaki)," Jurnal Washiyah 1, no. 3 (2020), p. 659.

10 Suhendrik, "Peran Youtube Dalam Pengembangan Da'wah Islam Dan Penyebaran Paham Keagamaan (Studi Channel Kh Syakur Yasin Ma/ Wamimma Tv)," Risalah, Jurnal Pendidikan Dan Studi Islam 7, No. 1 (2021), p. 17.

11 Ahmad Zaini, “Retorika Dakwah Mamah Dedeh Dalam Acara ' Mamah \& Aa Beraksi ' Di Indosiar" 11 (2017): 219-34, https:// doi.org/10.15575/idajhs.v12i.1900. 
kyai yang paham masalah agama. Nikah sirri tersebut menimbulkan dampak salah satunya anak yang lahir akibat pernikahan sirri tidak mendapatkan perlindungan hukum. ${ }^{12}$ Penelitian ini memfokuskan pada nikah sirri menurut Islam serta memaparkan dampak yang terjadi ketika pernikahan sirri dilangsungkan.

Muhammad Thahir mengungkapkan bahwa anak yang lahir akibat pernikahan sirri hanya mempunyai hubungan keperdataan dengan ibu saja. Ia juga mengungkapkan latarbelakang terjadinya nikah sirri ialah adanya faktor ekonomi dan proses administrasi nikah dianggap sukar. Penelitian ini senada dengan penelitian yang dilakukan oleh Asripa yaitu melihat nikah sirri dari Hukum Islam. ${ }^{13}$ Lalu Ali Akbar menemukan bahwa nikah sirri ternyata tidak hanya dilakukan karena tekanan ekonomi, tetapi karena ingin melakukan poligami secara diam-diam dengan alasan takut melakukan pergaulan bebas. Ia mengemukakan bahwa pernikahan sirri yang terjadi sekarang tidak sesuai dengan pemahaman pernikahan sirri terdahulu, karena Rasul menyuruh untuk yang melakukan pengumuman bagi yang sudah melakukan pernikahan dengan cara kenduri atau syukuran. ${ }^{14}$

Endang meneliti tentang nikah sirri melalui pespektif Hukum Islam dan Hukum Positif. Ia mengatakan bahwa pernikahan sirri yang dilakukan zaman sekarang dengan zaman dahulu berbeda. Nikah sirri (sembunyi-sembunyi) atau rahasia dilarang dalam Hukum Islam, namun pengertian tersebut diinterpretasikan bahwa pernikahan sirri adalah pernikahan yang memenuhi rukun dan syarat pernikahan. Selain itu pernikahan harusnya dicatatkan sebagaimana analogikan dengan hukum pencatatan jual beli. Pernikahan sirri tidak bisa memberikan perlindungan dan hak kepada istri dan anaknya kelak. Salah satu alasan mengapa pernikahan sirri masih dilakukan adalah karena masyarakat bersifat apatis dan kurang kesadaran dalam memahami hukum Masyarakat. ${ }^{15}$

${ }_{12}$ Asripa Asripa, “Nikah Sirri Dalam Perspektif Islam," Imtiyaz: Jurnal Ilmu Keislaman 4, No. 1 (2020), p. 54., https://doi.org/10.46773/imtiyaz.v4i1.64.

${ }_{13}$ M. Thahir Maloko, "Nikah Sirri Perspektif Hukum Islam," Sipakalebbi' Vol 1, no. Vol 1, No 3 (2015) (2015), p. 235.

14 Ali Akbar, "Nikah Sirri Menurut Perspektif Al-Quran," Jurnal Ushuluddin XXII, no. 2 (2014), p. 213.

${ }^{15}$ Endang Zakaria and Muhammad Saad, "Nikah Sirri Menurut Hukum Islam Dan Hukum Positif," Kordinat | Jurnal Komunikasi Antar Perguruan Tinggi Agama Islam XX, no. 2 (2021), p. 235. 
Penelitian yang berkaitan dengan dakwah yang dilakukan oleh Ustadz Abdul Somad di media sosial Youtube pernah dilakukan oleh Hidayati, ia mengungkapkan bahwa pemaparan Ustadz Abdul Somad dalam Youtube mempengaruhi masyarakat dalam memahami Islam dengan santun tanpa mengurangi prinsip-prinsip Islam yang sebenarnya. Ia juga mampu untuk mereka menyatukan dan merekatkan perkara-perkara yang sudah tuntas. Hidayati membahas tausiyah Ustadz Abbdul Somad secara global. Media sosial merupakan wasilah dakwah, yaitu alternatif untuk menyebarkan Islam. ${ }^{16}$

Penelitian-penelitian terdahulu tidak ada yang spesifik membahas tentang interpretasi nikah sirri yang diambil dari pemaparan pendakwah melalui Youtube. Oleh karena itu penulis memfokuskan pembahasan nikah sirri yang dikemukakan oleh pendakwah melalui Youtube. Youtube merupakan media yang mudah diakses oleh semua golongan, sehingga informasi atau tausiyah pendakwah menjadi salah satu rujukan. Penulis memilih fokus pada 2 pendakwah yaitu Mamah Dedeh dan Abdul Somad. Penulis memilih 2 pendakwah tersebut karena kedua pendakwah tersebut banyak membahas tentang nikah sirri dan mempunyai viewer terbanyak dibandingkan dengan pendakwah lain yang membahas tema yang sama. Banyaknya viewer tersebut membuat masyarakat banyak melihat dan menjadikan pemaparan pendakwah sebagai rujukan. Penulis memfokuskan pembahasan tentang apakah kedua pendakwah tersebut mempunyai interpretasi yang sama mengenai nikah sirri? Apakah kedua pendakwah tersebut mengaitkan hukum nasional dalam ceramahnya?

\section{B. Interpretasi Pendakwah Mengenai Nikah Sirri di Youtube}

Pendakwah merupakan salah satu panutan yang dijadikan rujukan oleh masyarakat dalam hal agama dan yang berkaitan dengan itu. Mamah Dedeh dan Ustadz Abdul Somad misalnya, dijadikan sebagai panutan masyarakat melalui tausiyah di media Youtube. Paper ini fokus pada pemabahasan nikah sirri yang dikemukakan oleh Mamah Dedeh dan UAS di Youtube. Tausiyah melalui media

16 Hayati Islami, Agustina, and Rochman, "Pemikiran Dan Aktivitas Dakwah Ustadz Abdul Somad Melalui Media Sosial Youtube." Tsaqila: Jurnal Komunikasi dan Penyiaran Islam. Vol 1 No 1 (2020), p. 58. 
dinilai mampu menyebarluaskan tausiyah menjadi lebih luas untuk masyarakat. Oleh karena itu konten Youtube menampilkan kembali tausiyah Mamah Dedeh maupun Ustadz Abdul Somad.

Ustadz Abdul Somad yang akrab dipanggil UAS merupakan salah satu dai agama yang tersohor di Riau. Sejak kecil ia sekolah dan mendapatkan pendidikan keagamaan, mulai dari Al-Quran, akidah, fiqh politik Islam dan lain-lain. Pendidikan keagamaan tersebut ia perdalam hingga pendidikan doktor di Sudan. Latarbelakang ilmu keagamaan, ia diberikan amanah untuk menjadi dosen di UIN Sultan Syarif Kasim Riau (SUSKA). Ilmu yang beliau dapat akhirnya disebarluaskan mulai dari satu kampung ke kampung yang lain. ${ }^{17}$ Sejalan dengan UAS, Mamah Dedeh juga mempunyai latarbelakang keluarga yang mempunyai agama yang kuat. Ia merupakan anak dari kyai Sujai. Hidup dalam lingkungan agama yang ketat membuat Mamah Dedeh mulai terbiasa ceramah sejak SD. Gaya bicara ceplas ceplosnya membuat respon baik itu muncul dari masyarakat. Tempat kelahirannya adalah Ciamis, sehingga tidak heran jika khas ceramahya ceplas ceplos. ${ }^{18}$ Banyak hal yang disampaikan oleh kedua pendakwah di atas (UAS dan Mamah Dedeh) mengenai Hukum keagamaan, salah satunya membahas tentang Nikah Sirri.

Mamah Dedeh misalnya mengungkapkan bahwa nikah sirri bukan yang dipahami sekarang ini tidak sesuai dengan istilah nikah sirri yang dikemukakan menurut Islam. Beliau mengatakan dalam ceramahnya bahwa nikah dalam Islam tidak ada istilah nikah sirri, melainkan nikah sah dalam Islam ialah harus memenuhi 5 syarat, yaitu adanya calon mempelai laki-laki, calon mempelai perempuan, wali, dua orang saksi dan ijab qobul, jika lima syarat tersebut terpenuhi maka pernikahan tersebut sah. Tetapi di Indonesia mempunyai aturan yang tertuang dalam Undangundang Nomor 1 Tahun 1974 yang mengatakan bahwa apabila suami dan istri yang beragama Islam maka jika ingin menikah maka harus dicatatkan ke Kantor Urusan

17 DONY ARUNG TRIANTORO, "USTAZ YOUTUBE: USTAZ ABDUL SOMAD DAN DINAMIKA PERUBAHAN OTORITAS KEAGAMAAN," Jurnal PENAMAS 33 (2020): 205-24.

${ }_{18}$ Ahmad Zaini, "Analisis Metode Ceramah Mamah Beraksi Di Indosiar Dengan Tema ' Orang Ketiga Perusak Keluarga ,'” AT-TABSYIR: Jurnal Komunikasi Penyiaran Islam 4, no. 2 (2016): 213-28. 
Agama (KUA), namun jika keduanya tidak beragama Islam maka pernikahan tersebut dicatatkan ke Catatan Sipil. ${ }^{19}$

Mamah Dedeh memahami bahwa pernikahan sirri yang dilakukan sekarang ini berbeda pemahaman, jika pemahaman pernikahan sirri yang dilakukan dahulu semuanya memenuhi lima syarat di atas, namun pernikahan sirri yang dilakukan sekarang dipahami berbeda. Misalnya pernikahan sirri yang dilakukan dengan tanpa adanya wali merupakan kategori pernikahan sirri, padahal jika mengacu lima syarat di atas wali merupakan salah satu syarat yang harus dipenuhi. Tidak adanya wali menjadikan salah satu syarat tersebut tidak tidak terpenuhi, sehingga apabila suami istri yang menikah (tanpa wali) lalu melakukan hubungan badan, maka mereka melakukan perbuatan zina. ${ }^{20}$

Ustadz Abdul Somad (UAS) juga mengemukakan tentang syarat pernikahan, namun syarat pernikahan yang ia kemukakan ialah harus memenuhi enam syarat. Yang membedakan salah satu syarat antara kedua pendakwah terletak pada adanya mahar dan tidak. Dalam ungkapan Mamah Dedeh tidak memasukkan mahar sebagai salah satu syarat pernikahan, sedangkan UAS memasukkan mahar menjadi salah satu syarat. UAS melalui tausiyah di youtube tidak mengatakan secara langsung bahwa perbedaan pernikahan sirri sesuai dengan hukum Islam dan hukum nasional. Ia hanya mengungkapkan dan menceritakan bahwa ia menemukan kasus pernikahan sirri yang dilakukan karena tidak adanya wali. Ia mengungkapkan dalam tausiyahnya bahwa ada kasus pernikahan sirri yang dilakukan dengan tanpa adanya saksi, orang yang mau menikah sirri tersebut ditanya alasan mengapa melakukan pernikahan sirri tanpa wali, ia mengatakan bahwa "aku nikah dengan kamu dengan disaksikan para malaikat". Maka pernikahan demikian (tanpa wali atau saksi) tidak sah. ${ }^{21}$

Tausiyah UAS yang lain mengungkapkan bahwa nikah sirri tidak hanya dipahami pernikahan yang tidak dicatatkan, tetapi nikah sirri di fahami pernikahan

19 Youtube, "Mamah Dan Aa Beraksi- Nikah Sirri, Solusi Atau Intimidasi," https://www.youtube.com/watch?v=BObZKe6F_Uo\&t=1s.

${ }^{20}$ Ibid.,.

21 Youtube, "Abdul Somad Hukum Nikah Sirri, di akses pada tanggal 11 November 2021 https://www.youtube.com/watch?v=hQFQcchy6Xk.. 
yang dilangsungkan tanpa adanya wali ataupun saksi. Sebagaimana tausiyah UAS ketika membahas nikah sirri:

"Nikah sirri berdosa atau tidak? Nikah sirii kalau cukup syaratnya maka tetap sah. Wali? Ada. Saksi? Ada dan lain-lain. Nikah sirri yang tidak sah apabila seorang lakilaki dengan perempuan berduaan di hotel lalu mengatakan "saya terima nikahnya dan kawinnya fulanah dengan uang 50 ribu sampai jam 5 sore tunai". saya mengingatkan agar tidak melakukan nikah sirri karena jika ingin mengurus akta nikah payah, mau menuntut waris payah, apalagi jika istri pertamanya galak. Bagi seseorang yang ingin menikah lagi payah. Karena takliknya digantung oleh suami."22

Pernikahan tanpa dicatatkan beresiko untuk perempuan yaitu tidak adanya payung hukum yang bisa melindungi perempuan karena tidak adanya data autentik. Dalam akta nikah terdapat shigat taklik yang mengikat suami. Sebagaimana yang dipaparkan oleh UAS dalam ceramahnya:

"Shigat taklik "jika saya meninggalkan istri lebih dari 3 bulan lamanya, tidak memberikan nafkah lahir dan batin, atau menyakiti fisiknya, maka istri melapor ke pengadilan agama dan hakim menjatuhkan talak 1, maka jatuhlah talak 1 kepada istrinya. Hai perempuan, jangan mau nikah sirri. Nikahnya harus jelas. Ada suami, ada istri, ada saksi, ada wali, ada mahar, ada ijab dan ada qobul. Jika tidak ada ini jangan mau menikah, karena yang rugi adalah perempuan. Laki-laki enak, ia datang-datang-datang lalu hamil. Yang mengandung dan melahirkan kan kalian. Jika sudah ada calon mempelai laki-laki dan perempuan maka segeralah di ikat dengan pernikahan yang sah."

Kesempatan yang lain, UAS menyampaikan bahwa adanya pernikahan sirri yang dilakukan oleh anak sekolah atau orang yang bekerja. Pernikahan sirri ini dilakukan karena adanya salah satu syarat yang tidak dipenuhi. Tidak adanya wali misalnya, membuat mereka melangsungkan pernikahan secara sirri. "aku menikah dengan kamu, disaksikan para malaikat". Tentu pernikahan tersebut tidak sah karena tidak memenuhi syarat. Pernikahan sirri trsebut seringkali di lakukan karena suami yang ingin menikah lagi tetapi tidak berani meminta izin kepada istri pertama. Hal itu berdampak pada ketidaknyamanan istri pertama, waris anak yang dihasilkan dari pernikahan sirri tidak bisa mengurus surat akta lahir hingga berdampak pada tidak bisa saling mewarisi. Oleh karena itu pernikahan sirri yang dilakukan itu yang dirugikan adalah perempuan. ${ }^{23}$

\footnotetext{
22 Youtube, "Abdul Shomad Hukum Nikah Sirri," https: / / www.youtube.com/watch?v=8Y5OTwBiw-0. di akses pada tanggal 12 November 2021.

${ }^{23}$ Youtube.
} 
Syarat wali dalam pernikahan bertujuan untuk memelihara dan menjaga anak perempuan yang akan menikah. Adanya wali tersebut bukan digunakan orang tua untuk memaksa menikahkan anaknya, tetapi wali memberikan masukan dan saran serta memberikan pertimbangan kepada anaknya yang akan melangsungkan pernikahan. Sayyid Sabiq mengasumsikan bahwa perempuan seringkali mementukan sesuatu dipengaruhi oleh perasaannya. Oleh sebab itu perempuan dinilai tidak pandai memilih dan tidak bisa memperoleh tujuan-tujuan utama dalam pernikahan jika tanpa arahan dan pertimbangan wali. 24

Tausiyah kedua pendakwah tentang pemahaman nikah sirri yang terjadi di masyarakat sedikit berbeda. Mamah Dedeh secara tegas menjelaskan bahwa pernikahan sirri yang terjadi sekarang ini tidak sesuai dengan nikah sirri yang dimaksud oleh para ulama' terdahulu. Nikah sirri terdahulu memenuhi semua syarat dan tidak dilakukan dengan sembunyi-sembunyi. Sedangkan UAS tidak memaparkan secara langsung tentang praktik nikah sirri yang dipahami oleh ulama' terdahulu dan praktik yang sekarang. Selain perbedaan tersebut, keduanya juga berbeda dalam syarat pernikahan yang harus dipenuhi oleh orang yang melangsungkan pernikahan.

Pemahaman Mamah Dedeh dan UAS memperkuat penelitian yang dilakukan oleh Kholil tentang tanggapan nikah sirri. Paper tersebut menjelaskan bahwa terdapat dua pendapat yang berbeda mengenai nikah sirri. Pendapat yang pertama setuju dengan adanya pernikahan sirri yang memenuhi semua syarat dan rukun pernikahan, tetapi pernikahan tersebut tidak dicatatakan ke KUA. Sedangkan pendapat yang kedua tidak setuju dengan adanya pernikahan sirri karena pernikahan harus dilakukan secara terbuka, bukan secara sembunyi-sembunyi. Hal tersebut menjadikan banyak madharat yang akan terjadi ketika pernikahan tersebut tidak dicatatkan ke KUA. Karena meskipun sah menurut agama tetapi jika

${ }^{24}$ Dahlia Haliah Ma'u, "Nikah Sirri Dan Perlindungan Hak-Hak Wanita Dan Anak (Analisis Dan Solusi Dalam Bingkai Syari'ah)," Al-Ahkam: Jurnal Ilmu Syari'ah Dan Hukum 1, no. 1 (2016), p. 4041. https://doi.org/10.22515/al-ahkam.v1i1.81. 
dilakukan beraktibat fatal. Oleh karena itu meskipun agama memperbolehkan tetapi harus mengikuti ulil amri untuk melakukan pencatatan pernikahan. ${ }^{25}$

Ashari mengkategorikan nikah sirri menjadi 4 kategori. Kategori pertama ialah pernikahan yang dilakukan karena sudah memenuhi rukun dan syaratnya tetapi tidak dilaksanakan pencatatan ke Pegawai Pencatat Nikah serta belum diadakannya acara walimahan. Hal ini dilakukan karena suami dan istri belum tinggal dan hidup bersama, melainkan masih tinggal dengan orang tua. Pemisahan itu dilakukan karena salah istri masih belum dewasa. Kategori kedua ialah pernikahan sirri yang dilakukan karena sudah terpenuhi syarat dan rukunnya namun karena salah satu pasangan sedang studi sehingga keduanya belum tinggal bersama meskipun pernikahannya sudah di catatkan ke Pegawai Pencatat Nikah. Sedangkan kategori yang ketiga ialah pernikahan yang dilakukan secara sembunyi-sambunyi atau rahasia karena terhalang untuk mempunyai istri lebih dari 1 untuk Pegawai Negeri Sipil. Hal itu dilakukan supaya suami tidak mendapatkan hukuman pemberhentian dengan tidak hormat dari instansi tempat ia bekerja. Lalu kategori yang terakhir ialah pernikahan yang sudah memenuhi syarat dan ketentuannya tetapi tidak dicatatkan ke Pegawai Pencatatan Nikah. ${ }^{26}$

\section{Pemaparan Pendakwah Mengenai Nikah Sirri dalam Aturan Hukum Islam dan Hukum Nasional di Indonesia.}

Undang-undang Perkawinan Nomor 1 Tahun 1974 mengatur tentang pernikahan. Pasal 2 dalam undang-undang tersebut mengatur bahwa "pernikahan adalah sah jika dilakukan menurut agama dan kepercayan", lalu disambung dengan "tiap-tiap pernikahan dicatatkan menurut undang-undang yang berlaku". Aturan tersebut jelas mengatakan bahwa pernikahan yang terjadi di Indonesia harus dicatatakan tanpa terkecuali. Sedangkan mengenai syarat pernikahan, Undangundang perkawinan mengatur bahwa pernikahan harus didasarkan atas persetujuan

${ }^{25}$ Kholil, Ibdalsyah, and Rafdi, "Nikah Sirri Dalam Perspektif Kiyai Nahdlatul Ulama (Studi Kasus Kabupaten Bogor)." Jurnal Akbar Juara Volume 6 No 3 Edisi Agustus (2021), p. 50-51.

${ }^{26}$ Ashadi L Diab, "Legalisasi Nikah Sirri Melalui Isbat Nikah Perspektif Fikih ( Telaah Terhadap Kompilasi Hukum Islam)," Jurnal Al-'Adl Vol. 11 No. 2, Juli 2018 11, no. 2 (2018), p. 42-44. 
kedua mempelai. ${ }^{27}$ Interpretasi nikah sirri mengalami perkembangan dimulai dari ucapan Umar bin khattab ketika adanya pernikhana yang tidak dihadiri oleh saksi kecuali seorang laki-laki dan perempuan (kedua mempelai). Lalu beliau mengatakan "ini pernikahan sirri dan aku tidak memperbolehkannya. Sekiranya aku datang, maka keduanya pasti saya rajam". ${ }^{28}$

Kompilasi Hukum Islam mengatur bahwa agar terjaminnya ketertiban perkawinan di masyarakat harus di catatkan. Pencatatan perkawinan yang sah dicatatkan ke Pegawai Pencatat Nikah yang di atur di Undang-undang Nomor 22 Tahun 1946 jo Undang-Undang No 32 tahun 1954.29 Selanjutnya perkawinan yang dicatatkan ke Pegawai Pencatat Nikah hanya dibuktikan dengan akta nikah. Apabila perkawinan tersebut tidak bisa dibuktikan melalui akta nikah, maka mempelai lakilaki dan perempuan mengajukan istbat nikah ke Pengadilan Agama. Hal-hal yang bisa diajukan untuk meminta isbat nikah ke Pengadilan Agama adalah hilangnya akta nikah, kurangnya salah satu syarat perkawinan, adanya perkawinan yang dilaksanakan sebelum tahun 1974, perkawinan yang sudah dilakukan.30

Hukum Islam dan hukum Negara seringkali dipaparkan sendiri-sendiri oleh penceramah, seakan-akan kedua hukum tersebut tidak bisa saling melengkapi dan menguatkan. Seolah-olah keduanya saling bertentangan dan tidak bisa disatukan. Oleh karena itu penulis memfokuskan pembahasan tentang pemaparan Mamah Dedeh dan UAS dalam youtube, apakah keduanya membedakan antara hukum Islam dan hukum Negara dalam memberikan tausiyah kepada khalayak umum? Ataukah keduanya menyampaikan aturan negara dan aturan agama secara bersamaan. Penulis mencoba memaparkan melalui tausiyah kedua pendakwah yang diulas di bawah.

Nikah Sirri diartikan sebagai pernikahan yang dilakukan secara rahasia atau diam-diam, sedangkan dalam pengertian hukum positif diartikan sebagai pernikahan yang dilakukan diluar pengawasan petugas sehingga tidak tercatatkan

27 Undang-Undang No 1 Tahun 1974 tentang Perkawinan), pasal 6.

28 U Syafrudin, "Islam Dan Budaya: Tentang Fenomena Nikah Sirri," Mahkamah: Jurnal Kajian Hukum Islam 9, no. 1 (2015), p. 19.

${ }^{29}$ Kementrian Agama RI, Kompilasi Hukum Islam Di Indonesia, 2018.

${ }^{30}$ Kementrian Agama RI. 
ke KUA. Oleh karena itu pernikahan sirri diartikan sebagai pernikahan illegal. ${ }^{31}$ Pernikahan Sirri di Indonesia difahami dua kategori. Pemahaman yang pertama adalah nikah sirri yang dilakukan karena tanpa adanya wali, sedangkan pemahaman yang kedua adalah pernikahan yang tidak dicatatkan ke KUA. Kedua pemahaman tersebut masih dilakukan oleh masyarakat, bukan hanya masyarakat biasa, tetapi dilakukan oleh para pejabat. Hal itu bisa dilihat melalui media social. ${ }^{32}$ Peraturan yang diberlakukan di Indonesia mengharuskan pernikahan tersebut dicatatkan ke Kantor Urusan Agama (KUA), namun aturan tersebut tidak sepenuhnya ditaati oleh masyarakat karena masih banyaknya pernikahan yang dilakukan tanpa dicatatkan ke KUA. Hal itu bertentangan dengan ketentuan Undang-undang tentang Perkawinan yang tertuang dalam pasal 2 ayat 2. Nyatanya praktik pernikahan di Indonesia masih ada yang tidak dicatatkan ke KUA, mulai dari tidak mendapatkan restu atau persetujuan wali. Kesempatan tersebut digunakan oleh jasa nikah yang menyediakan jasa pernikahan sirri secara online. Hal itu bertentangan dengan sebagian pendapat yang mengharuskan pernikahan dilakukan dalam satu majelis atau satu tempat. ${ }^{33}$

Mamah Dedeh menyampaikan secara langsung mengenai pernikahan, beliau mengatakan bahwa pernikahan tidak hanya memenuhi lima syarat yaitu adanya calon mempelai laki-laki, calon mempelai perempuan, dua orang saksi, wali dan ijab qabul, tetapi pernikahan tersebut juga harus dicatatakan sebagaimana yang tertuang dalam aturan Undang-undang Perkawinan Nomor 1 Tahun 1974 tentang perkawinan. Beliau mengatakan bahwa apabila kedua mempelai beragama Islam maka dicatatkan ke Kantor Urusan Agama (KUA), sedangkan jika kedua mempelai non muslim maka percatatannya dilakukan di Catatan Sipil.34

Tausiyah yang disampaikan oleh Mamah Dedeh di awali oleh Abdel:

${ }^{31}$ Muhammad Alfatih Suryadilaga, "Nikah Sirri Dalam Perbincangan Media Masa," Musâwa, Vol. 12 No 1 Januari 2013 12, (2013), p. 106.

32 Kholil, Ibdalsyah, and Rafdi, "Nikah Sirri Dalam Perspektif Kiyai Nahdlatul Ulama (Studi Kasus Kabupaten Bogor)," Jurnal Akrab Juara 6, no. 3 (2021), p. 47.

${ }_{33}$ Reza Saputra, "Tinjauan Hukum Islam Terhadap Nikah Sirri Online (Kajian Tentang Tata Cara Pelaksanaannya)," Al-Qoonun - Jurnal Hukum Keluarga Islam 1, no. Agustus (2018), p. 100.

34 Youtube, "Mamah Dan Aa Beraksi- Nikah Sirri, Solusi Atau Intimidasi". https:// www.youtube.com/watch?v=BObZKe6F_Uo\&t=1s. diakses pada tanggal 10 November 2021 
"Pernikahan sejatinya harus sah di mata agama dan sah secara negara juga, karena pernikahan merupakan peristiwa yang sakral. Antara suami dan istri juga mempunyai hak dan kewajiban dalam rumah tangga. Oleh karen itu pernikahan yang baik itu adalah pernikahan yang dicatatkan negara supaya hak-hak perempuan dapat terlindungi dengan baik. Bagaimana jika terjadi pernikahan sirri yang tidak di catatkan ke KUA? Apakah ini merupakan solusi atau intimidasi untuk perempuan?"

Mamah Dedeh menyampaikan secara tegas untuk perempuan untuk tidak melakukan pernikahan tanpa di catatakan. Dalam tausiyahnya beliau mengungkapkan bahwa jadi perempuan jadi mau di nikahi sirri karena nantinya yang akan rugi adalah perempuan. Laki-laki merayu dan membujuk seorang perempuan, karena ia menginginkannya untuk menikahinya (tanpa dicatatkan), setelah menikah, lalu laki-laki tersebut merasa bosan dan menginggalkan perempuan. Lalu perempuan yang dinikahi sirri tersebut meu menuntut kemana? Sedangkan pernikahan yang dijalankan adalah pernikahan yang tidak dicatatkan. Dampak lain adalah susah akta lahir anak, karena untuk mengurus administrasi akta lahir mengharuskan adanya akta nikah dari orang tuanya. Dampak lainnya untuk perempuan yang dinikahi secara sirri adalah apabila suaminya meninggal dunia, maka keduanya tidak bisa saling mewarisi. Jika ia di ceraikan oleh suami maka perceraiannya digantungkan, istri tidak bisa menuntut apa-apa kepada suami karena tidak ada bukti. ${ }^{35}$

Dampak lain yang diungkapkan oleh Mamah Dedeh yang beliau contohkan adalah:

Apabila seorang laki-laki PNS menikah kedua kalinya maka ia harus izin dari istri pertama. Harus ada tulis tangan dari pihak istri pertama, namun suami tidak berani meminta izin kepada istri pertama maka untuk menghindari hal tersebut dilakukanlah pernikahan sirri. Yang dirugikan perempuan juga. Saya mohon kepada ustadz atau kyai jangan menikahkan keluarga anda, saudara anda dengan menikahkan sirri karena yang akan menjadi korban adalah perempuan. Menjadi perempuan juga jangan mau merendahkan diri kita karena kita mempunyai aturan dan undangundang. Kalau yang beragama Islam maka dicatatkan ke KUA dan yang tidak beragama Islam di catatkan ke catatan sipil. Semoga keluarga kita sakinah, mawaddah warrahmah. 36

\footnotetext{
35 Ibid.,.

36 Ibid.,
} 
Tausiyah yang dilakukan Mamah Dedeh terdapat sesi diskusi atau tanya jawab. Ada seorang ibu yang bertanya kepada Mamah Dedeh terkait rencana nikah sirri yang akan dilakukan oleh temannya. "Mah, teman saya belum menikah, ia berusia seumuran dengan saya kisaran 40 tahunan. Ia bercerita kepada saya bahwa ada seorang lakilaki yang mengajak ia menikah tetapi laki-laki tersebut menikahi teman saya secara sirri atau dijadikan istri simpanan. Bagaimana solusi yang bisa saya sampaikan kepadanya tanpa melukai perasaannya mah? Terima kasih". Ujar salah satu audiensi Mamah Dedeh. Lalu Mamah Dedeh memberikan tanggapan atas pertanyaan yang diajukan kepadanya: ${ }^{37}$

Sampaikan bahwa nikah sirri hanya merugikan perempuan. Jamaah saya ada yang mengalami hal yang serupa. Ia sudah berusia dan ada yang mengajak menikah. Ia mengatakan yang penting status saya jelas, namun setelah menikah ia ingin meminta hak nafkah (rumah dkk), minta dipelukin, ingin dibelai dan lain-lain. Ini sejak awal sudah salah, sampaikan sejak awal supaya tidak ada penyesalan. Jelaskan kepada teman anda bahwa jangan sampai ada penyesalan seperti teman saya tadi.

Pengingkaran suami terhadap istri yang dinikahinya secara sirri menimbulkan polemik, karena perempuan yang di nikahi secara sirri tidak bisa membuktikan bahwa keduanya merupakan suami istri. Selain pengingkaran, suami bisa menggantung nasib istri dengan cara mendiamkan istri tanpa menceraikan istri. Sehingga istri tidak bisa melakukan pernikahan dengan pria lain. Selain itu ketika salah satu dari suami atau istri meninggal, maka keduanya tidak bisa saling mewarisi. Tidak hanya suami istri tetapi juga berdampak kepada anak akibat pernikahan sirri. ${ }^{38}$

Ustad Abdul Somad tidak menegaskan secara langsung sebagaimana yang disampaikan oleh Mamah Dedeh. UAS sekedar menyarankan kepada perempuan untuk tidak melakukan pernikahan sirri karena bahaya. Beliau memberikan contoh kasus:

"Misalnya suami merantau selama 10 tahun, maka istri tidak bisa menikah meskipun ditinggal 10 tahun maka ia tetap tidak bisa menikah dengan orang lain karena ia terikat. Bedaya kalau ia menikah di KUA maka suami diikat dengan taklik talak "jika saya meninggalkan istri saya selama 3 bulan lamanya, atau menyakiti fisiknya, lalu ia mengadu kepada pengadilan lalu kemudian hakim mengabulkan gugatannya maka jatuhlah taklik satu

37 Youtube.

38 Moh. Nailul muna, "Mendialogkan Legitimasi Nikah Sirri Dalam Ranah Teologis Dan Yuridis (Interpretasi Hadits Larangan Nikah Sirri Dalam Perspektif Antropologi)," Ta'Limuna, Vol.7, No. 1, Maret 2018 7, No. 1 (2018), p. 1-12. 
kepada istri. Nah jika nikah sirri maka tidak bisa meskipun ditinggal 100 tahun. Sebab tidak adanya talak karena talak tersebut tidak bisa jatuh ke pengadilan karena pernikahan tersebut tidak dicatatkan. Jika 6 syaratnya terpenuhi maka pernikahan tersebut tetap sah". ${ }^{39}$

Tausiyah lain, UAS mengatakan bahwa pernikahan sirri tidak ada untungnya. Karena pengadilan tidak mau menerima gugatan tanpa adanya bukti. ${ }^{40}$ Begitu juga ketika istri ditinggal mati oleh suaminya, maka ia tidak bisa menuntut harta waris. Sebagaimana tausiyahnya:

"Wahai perempuan, jangan mau menikah sirri, karena ketika kamu ditinggal mati oleh suamimu, maka kamu tidak bisa mendapatkan harta warisan. Apabila kamu menuntut harta warisan, maka akan ditanya bukti hitam di atas putih. Foto kami selfi? Tidak laku. Kedua, kalau suami mu pergi, kamu tidak bisa menuntut ke pengadilan, kalau nikahnya resmi bisa. Kenapa? Karena selepas akad, suami membaca shigat taklik. Seringkali istri lupa bahwa suami pernah mengikrarkan shigat taklik "Ustadz, suami saya tidak memberikan nafkah selama 2 tahun kepada saya pak". terus bagaimana pak ustadz? Bagaimana saya bisa lepas pak? Mengajukan ke pengadilan. Kan sewaktu shigat taklik suami mengucapkan shigat taklik itu. Mungkin waktu itu istri sedang asik selfi."41

Pernyataan di atas senada dengan Marita, ia mengungkapkan bahwa pernikahan sirri sangat mudah dilakukan di era digitalisasi seperti sekarang. Suami bisa melakukan pernikahan sirri dimana saja tanpa diketahui oleh istri dan anaknya terlebih dahulu. Selain itu anak yang dihasilkan dari pernikahan sirri menjadikan asal usul hubungan darah antara ayah, bapak dan cucu tidak diketahui dengan baik. Karena tidak adanya bukti autentik yang resmi dikeluarkan oleh pemerintah yaitu akta nikah. ${ }^{42}$ Selain dampak nikah sirri, ternyata terdapat alasan-alasan terjadinya pernikahan sirri itu masih saja terjadi di masyarakat.

Eva mengungkapkan salah satu maraknya pernikahan sirri marak dilakukan dalam kondisi Covid-19 melanda dunia. Alasan yang dikemukakan ialah karena aturan yang melarang untuk dilakukannya pernikahan digalakan diberbagai daerah. Pelarangan tersebut membuat kedua mempelai diminta untuk bersabar untuk

39 Youtube, "Abdul Shomad Hukum Nikah https://www.youtube.com/watch?v=hQFQcchy6Xk. di akses pada tanggal 11 November 2021.

40 Youtube, "Abdul Somad Apa Hukum Nikah Sirri Pak Ustadz?," https:/ / www.youtube.com/watch?v=TAnQPIL85A4. diakses pada tanggal 11 November 2021.

41 Youtube, "Abdul Somad Jangan Mau Nikah Sirri," https://www.youtube.com/watch?v=QCr1mizaoGs. diakses pada tanggal 15 November 2021 .

42 Marita Lailia Rahman, "Nikah Sirri: Keabsahan Dan Akibatnya," Al Hikmah: Jurnal Studi Keislaman 8 (2018), p. 134. 
menunggu dibukanya kembali pernikahan ketika pandemi. Akhirnya mempelai yang tidak sabar untuk menunggu dibukanya kembali pernikahan ketika pandemi mengakibatkan terjadinya pernikahan sirri. Pernikahan sirri tersebut menimbulkan dampak negatif terutama bagi perempuan karena pernikahan sirri online seringkali merendahkan perempuan, bahkan salah satu media secara terang-terangan menyebutkan lelang keperawanan yang dipromosikan secara online. ${ }^{43}$ Dampak nikah sirri banyak merugikan perempuan, mulai dari antara suami dan istri tidak saling mewarisi, ayah tidak bisa menjadi wali nikah anak yang dihasilkan dari nikah sirri, melemahnya ketahanan keluarga, serta terkendala dalam mengurus administrasi kependudukan anak karena tidak adanya bukti autentik bahwa ayah dan ibunya tersebut sudah menikah. ${ }^{44}$

Berbeda dengan Eva, Zulfa menemukan bahwa terdapat 3 alasan mengapa masih terjadi pernikahan sirri di masyarakat. Pertama, suami menikahi seorang perempuan untuk menjadi istri kedua, namun istri pertama tidak mengetahui pernikahan tersebut. Oleh karena itu pernikahan tersebut dilakukan dengan cara sirri. Kedua, seorang duda atau janda yang sudah bercerai dengan mantan suami atau istri. Namun kedua calon mempelai memutuskan untuk melakukan pernikahan secara sirri. Ketiga, seorang Pegawai Negeri Sipil yang ingin menikah lagi tetapi terkendala administrasi dan lain hal. Sehingga nikah sirri dijadikan jalan keluar. ${ }^{45}$ Selain alasan administrasi tersebut, nyatanya perempuan dinikahi sirri oleh suaminya karena logika budaya di daerah tertentu meletakkan perempuan untuk mengurusi pekerjaan domestic. Hal tersebut membuat perempuan seringkali

${ }^{43}$ Eva Dwi Kumala Sari, "Literasi Keagamaan Mahasiswa Di Perguruan Tinggi Keagamaan Islam Negeri Uin Syarif Hidayatullah Jakarta," Jurnal Emanasi, Jurnal Ilmu Keislaman Dan Sosial Vol 3, No. 1, April (2020), p. 21-22.

${ }^{44}$ Zulfa Hudiyani et al., "Program Pengabdian Masyarakat Dalam Bentuk Penyuluhan Hukum Perkawinan Sirri Online Dan Regulasi MENAG Tentang Pencegahan Covid-19 Di Lingkungan KUA Pada Masyarakat Tanjungpinang," Jurnal Pengabdian Dan Pengembangan Masyarakat 1, No. 1 (2021), p. 21, https://doi.org/10.37680/muharrik.v4i01.234.

45 Zainuddin and Zaki Ulya, "Recording Siri's Marriages In Obtaining Legal Certainty (Reflections on the Rise of Siri Marriages in Aceh)," Syariah: Jurnal Hukum Dan Pemikiran 21, no. 1 (2021), p. 9-10. 
menyerahkan persoalan publik kepada laki-laki, bahkan sampai tidak mengetahui apakah ia dinikahi secara sirri atau dicatatkan ke KUA. ${ }^{46}$

Penelitian Pardianto mengungkapkan bahwa pencatatan pernikahan dianggap krusial karena perkawinan ialah ikatan perjanjian luruh dan perbuatan hukum yang paling tinggi, sehingga pernikahan tidak dianggap sekedar perjanjian biasa, namun perjanjian tersebut merupakan perjanjian yang sangat kuat. Sebuah kekeliruan jika pencatatan tersebut dianggap tidak penting. Pencatatan hutang piutang di perbankan atau jual beli tanah saja perlu dicatat, apalagi perihal perkawinan yang merupakan perjanjian paling tinggi. ${ }^{47}$

Perjanjian dalam perkawinan yang dianggap pejanjian paling tinggi tersebut diatur dan dilindungi dalam Kompilasi Hukum Islam (KHI), karena aturan dalam KHI menegaskan bahwa pencatatan pernikahan merupakan suatu keharusan. Selain pencatatan tersebut syarat pernikahan harus terpenuhi semua. Sehingga pencatatan tidak dijadikan sebagai faktor utama dalam menentukan sebuah sahnya pernikahan. Aturan "keharusan" dalam KHI tidak dibarengi dengan sanksi yang tegas. Sanksi hanya diberlakukan untuk petugas Pegawai Pencatat Nikah saja, tidak menyertakan sanksi yang tidak mendaftarkan pernikahannya ke KUA. Dengan demikian, aturan ini cenderung kabur. Akibatnya masih banyaknya terjadi pernikahan yang tidak dicatatkan ke KUA. ${ }^{48}$

Pencatatan pernikahan seharusnya mengikuti hukum Negara, lalu syarat dan rukunnya mengacu kepada hukum agama supaya keduanya saling berkaitan satu sama lain. Melalui pendekatan Antropologi, nikah sirri yang tidak memenuhi syarat dan rukun pernikahan maka dimaknai sebagai legalisasi prostitusi secara tidak langsung. ${ }^{49}$ Hal itu diperlukan solusi untuk menangani permasalahan nikah sirri.

46 Abd Aziz Faiz, "Pola Dan Logika Nikah Sirri Dalam Kultur Masyarakat Madura," Musãwa Jurnal Studi Gender Dan Islam 12, no. 1 (2013): 121, https:/ / doi.org/10.14421/musawa.2013.121.121135.

47 Pardianto, "MENELISIK FENOMENA NIKAH SIRI ( Sebuah Kajian Tematik Dalam Komunikasi Islam )," Jurnal Sulesana 12, no. 2 (2018), p. 31-32.

48 Euis Nurlaelawati, "Pernikahan Tanpa Pencatatan: Isbat Nikah Sebuah Solusi?," Musãwa Jurnal Studi Gender Dan Islam 12, no. 2 (2013): 261, https://doi.org/10.14421/musawa.2013.122.261277.

49 Nailul muna, "MENDIALOGKAN LEGITIMASI NIKAH SIRRI DALAM RANAH TEOLOGIS DAN YURIDIS (Interpretasi Hadits Larangan Nikah Sirri Dalam Perspektif Antropologi)." 
Salah satu yang solusi yang sedang dalam proses pengajuan undang-undang ialah Rancangan Hukum Materiil Peradilan Agama. Rancangan undang-undang tersebut diharapkan lekas disahkan menjadi undang-undang. Tujuannya agar tidak ada lagi yang meremehkan perkawinan. Selain itu RUU tersebut juga dapat mengisi kekosaingan hukum yang belum diatur dalam aturan yang berlaku di Indonesia. ${ }^{50}$

\section{Penutup}

Youtube menjadi salah satu media yang digunakan oleh pendakwah untuk menyebarkluaskan tausiyahnya ke media sosial. Sebelum adanya Youtube, masyarakat hanya bisa mengakses informasi secara langsung atau melalui televisi. Namun karena perkembangan teknologi, hadirlah Youtube yang menjadi salah satu daya tarik masyarakat untuk mencari aneka ragam ilmu yang bisa diakses kapanpun dan dimanapun. Informasi tersebut bisa disesuaikan dengan apa yang ingin diketahui. Tausiyah misalnya, masyarakat bebas untuk mengakses tausiyah siapapun. Tema juga bisa di sesuaikan dengan yang dibahas, nikah sirii misalnya, nikah sirri tidak hanya dipahami pernikahan yang tidak dicatatkan, tetapi nikah sirri juga dipahami pernikahan yang dilakukan secara sembunyi-sembunyi. Kedua pemahaman tersebut mempunyai dampak hukum yang berbeda. Pemahaman tersebut disampaikan oleh Mamah Dedeh dan UAS dalam ceramahnya di Youtube. Kedua penakwah tersebut mengatakan bahwa nikah sirri yang dilakukan tanpa adanya wali merupakan pernikahan yang tidak sah. Wali di nilai sebagai salah satu pertimbangan perempuan untuk melangsungkan pernikahan. Salah satu syarat adanya wali tidak sertamerta difahami untuk memaksakan anak untuk menikah dengan pilihan orang tuanya, tetapi sebatas untuk memberikan arahan dan pertimbangan untuk anak perempuannya terhadap laki-laki yang di pilihnya. Berbeda hal nya dengan pernikahan yang sudah memenuhi syarat pernikahan, tetapi belum dicatatakan. Mamah Dedeh secara tegas menyampaikan bahwa di Indonesia pernikahan haruslah dicatatkan sesuai hukum yang berlaku, sedangkan UAS tidak secara tegas menyampaikan bahwa Indonesia mempunyai aturan tentang pencatatan perkawinan, beliau sekedar menyarankan untuk tidak melakukan

${ }^{50}$ Khilyatus Sa'adah, "Pandangan Hakim PA Pasuruan Tentang Hukuman Pelaku Nikah Sirri Dalam RUU Hukum Materiil PA Bidang Perkawinan," Al-Qanun: Jurnal Pemikiran Dan Pembaharuan Hukum Islam 20, no. 1 (2020): 231-50, https:/ / doi.org/10.15642/alqanun.2017.20.1.231-250. 
pernikahan sirri (pernikahan tidak dicatatkan) karena menimbulkan banyak dampak negatif yang didapat oleh perempuan. Beliau masih mengatakan bahwa pernikahan yang memenuhi syarat maka sah. Sehingga UAS tidak secara langsung menyampaikan dalam tausiyahnya tetang aturan di Indonesia mengenai pencatatan perkawinan.

\section{DAFTAR PUSTAKA}

Alfatih Suryadilaga, Muhammad. "Nikah Sirri Dalam Perbincangan Media Masa." Musâwa, Vol. 12 No 1 Januari 2013 12, no. Januari 2013.

Ali Akbar. "Nikah Sirri Menurut Perspektif Al-Quran." Jurnal Ushuluddin XXII, no. 2 2014.

Arung Triantoro, Dony. "Ustaz Youtube: Ustaz Abdul Somad Dan Dinamika Perubahan Otoritas Keagamaan." Jurnal Penamas 332020.

Asripa, Asripa. “Nikah Sirri Dalam Perspektif Islam.” Imtiyaz: Jurnal Ilmu Keislaman 4, no. 12020 https://doi.org/10.46773/imtiyaz.v4i1.64.

Aziz Faiz, Abd. "Pola Dan Logika Nikah Sirri Dalam Kultur Masyarakat Madura." Musãwa Jurnal Studi Gender Dan Islam 12, no. 12013 https:/ / doi.org/10.14421/musawa.2013.121.121-136.

Basit, Abd, Misbachul Fitri, and Khusnul Kholik. "Pendampingan Pra Nikah Sebagai Solusi Mencari Pasangan Ideal Bagi Santri Senior Pondok Pesantren Miftahul Mubtadiin Putra Ar-Ridlo Krempyang Tanjunganom Nganjuk." JENAKA Jurnal Pengabdian Masyarakat STAI Darussalam Nganjuk3, no. 12020

Dwi Kumala Sari, Eva. “Literasi Keagamaan Mahasiswa Di Perguruan Tinggi Keagamaan Islam Negeri Uin Syarif Hidayatullah Jakarta." Jurnal Emanasi, Jurnal Ilmu Keislaman Dan Sosial (Vol 3, No. 1, April 2020) 3, no. 12020.

Haliah Ma'u, Dahlia. “Nikah Sirri Dan Perlindungan Hak-Hak Wanita Dan Anak (Analisis Dan Solusi Dalam Bingkai Syari'ah)." Al-Ahkam: Jurnal Ilmu Syari'ah Dan Hukum 1, no. 1 (2016). https:/ / doi.org/10.22515/al-ahkam.v1i1.81.

Hamdan, and Mahmuddin. "Youtube Sebagai Media Dakwah." Palita: Journal of Social Religion Research 6, no. 12021. 
Hayati Islami, Syifa, Lina Agustina, and M. Fathur Rochman. "Pemikiran Dan Aktivitas Dakwah Ustadz Abdul Somad Melalui Media Sosial Youtube." Tsaqila : Jurnal Komunikasi Dan Penyiaran Islam 1(1) 2020.

Hudiyani, Zulfa, Rizki Pradana Hidayatullah, Ahmad Jalili, Amrul Lutfi, and M Arbisora Angkat. “Program Pengabdian Masyarakat Dalam Bentuk Penyuluhan Hukum Perkawinan Sirri Online Dan Regulasi MENAG Tentang Pencegahan Covid-19 Di Lingkungan KUA Pada Masyarakat Tanjungpinang." JURNAL PENGABDIAN DAN PENGEMBANGAN MASYARAKAT 1, no. 12021. https://doi.org/10.37680/muharrik.v4i01.234.

Kementrian Agama RI. Kompilasi Hukum Islam Di Indonesia, 2018.

Kholil, Ibdalsyah, and Rafdi. "Nikah Sirri Dalam Perspektif Kiyai Nahdlatul Ulama (Studi Kasus Kabupaten Bogor)." Jurnal AKRAB JUARA 6, no. 32021.

L Diab, Ashadi. “Legalisasi Nikah Sirri Melalui Isbat Nikah Perspektif Fikih ( Telaah Terhadap Kompilasi Hukum Islam)." Jurnal Al-'Adl Vol. 11 No. 2, Juli 2018 11, no. 22018.

Lailia Rahman, Marita. "Nikah Sirri: Keabsahan Dan Akibatnya.” Al Hikmah: Jurnal Studi Keislaman 82018.

Mulyati, Farihatni. “Interpretasi Mitsaqan Ghalizan Dalam Surah An-Nisa ( 4 ) : 21 ( Pentingnya Pencatatan Pernikahan Menurut Hukum Islam )” 12, no. 222014.

Muslim, Abu. "Pergeseran Otoritas Ulama Magetan Akibat Fragmentasi Media Dakwah Baru Yang Ekonomis.” Spiritualis 5, no. Maret 2019.

Nailul muna, Moh. “Mendialogkan Legitimasi Nikah Sirri Dalam Ranah Teologis

Dan Yuridis (Interpretasi Hadits Larangan Nikah Sirri Dalam Perspektif Antropologi)." Ta'Limuna, Vol.7, No. 1, Maret 2018 7, no. 12018.

Nurlaelawati, Euis. "Pernikahan Tanpa Pencatatan: Isbat Nikah Sebuah Solusi?"

Musãwa Jurnal Studi Gender Dan Islam 12, no. 22013. https:/ / doi.org/10.14421/musawa.2013.122.261-277.

Pardianto. "Menelisik Fenomena Nikah Siri ( Sebuah Kajian Tematik Dalam Komunikasi Islam )." Jurnal Sulesana 12, no. 22018.

Sa'adah, Khilyatus. "Pandangan Hakim PA Pasuruan Tentang Hukuman Pelaku Nikah Sirri Dalam RUU Hukum Materiil PA Bidang Perkawinan." Al-Qanun: 
Jurnal Pemikiran Dan Pembaharuan Hukum Islam 20, no. 12020. https:/ / doi.org/10.15642/alqanun.2017.20.1.231-250.

Safitri, Alfiyani Nur, Asep Purwo, and Yudi Utomo. “Analisis Tindak Tutur Direktif Pada Ceramah Ustadz Abdul Somad Edisi Tanya Jawab Kajian Musawarah Bersama Artis Hijrah." ESTETIK: Jurnal Bahasa Indonesia 3, no. 22020. https://doi.org/10.29240/estetik.v3i2.1613.

Salam, Abdul, Muliaty Amin, and Kamaluddin Tajibu. "Dakwah Melalui Youtube (Analisis Pesan Dakwah Ustadz Hanan Attaki)." Jurnal Washiyah 1, no. 32020.

Saputra, Reza. “Tinjauan Hukum Islam Terhadap Nikah Sirri Online (Kajian Tentang Tata Cara Pelaksanaannya)." Al-Qoonun - Jurnal Hukum Keluarga Islam 1, no. Agustus 2018.

Suhendrik. "Peran Youtube Dalam Pengembangan Da'wah Islam Dan Penyebaran Paham Keagamaan (Studi Channel Kh Syakur Yasin MA/ WAMIMMA TV)." Risalah, Jurnal Pendidikan Dan Studi Islam 7, no. 12021.

Syafrudin, U. “Islam Dan Budaya: Tentang Fenomena Nikah Sirri.” Mahkamah: Jurnal Kajian Hukum Islam 9, no. 12015.

Tamrin Sikumbang, Ahmad, and Rahmi Fiutra Ulwani. "Youtube As a Da'Wah Media." Jurnal Al-Bayan: Media Kajian Dan Pengembangan Ilmu Dakwah 26, no. 2 2021.

Thahir Maloko, M. “Nikah Sirri Perspektif Hukum Islam.” Sipakalebbi’ Vol 1, no. Vol 1, No 32015.

“Undang-Undang No 1 Tahun 1974." Peraturan Pemerintah Republik Indonesia Nomor 26 Tahun 1985 Tentang Jalan 2003, no. 1 (1974): 2.

Youtube. "Abdul Shomad Hukum Nikah Sirri," n.d.

- - - "Abdul Somad Apa Hukum Nikah Sirri Pak Ustadz?," n.d.

- - - "Abdul Somad Hukum Nikah Sirri," n.d.

- - - . "Abdul Somad Jangan Mau Nikah Sirri," n.d.

- - - "Mamah Dan Aa Beraksi- Nikah Sirri, Solusi Atau Intimidasi," n.d.

Zaini, Ahmad. “Analisis Metode Ceramah Mamah Beraksi Di Indosiar Dengan Tema

'Orang Ketiga Perusak Keluarga .'” At-Tabsyir: Jurnal Komunikasi Penyiaran Islam 4, no. 22016. 
- - - “Retorika Dakwah Mamah Dedeh Dalam Acara 'Mamah \& Aa Beraksi ' Di Indosiar" 11 2017. https:/ / doi.org/10.15575/idajhs.v12i.1900.

Zainuddin, and Zaki Ulya. “Recording Siri”s Marriages In Obtaining Legal Certainty (Reflections on the Rise of Siri Marriages in Aceh)." Syariah: Jurnal Hukum Dan Pemikiran 21, no. 12021.

Zakaria, Endang, and Muhammad Saad. "Nikah Sirri Menurut Hukum Islam Dan Hukum Positif." Kordinat | Jurnal Komunikasi Antar Perguruan Tinggi Agama Islam XX, no. 22021. 